\title{
Utility of Acetazolamide-challenged CT Perfusion in Patients with High-grade Carotid Stenosis
}

\author{
Ho Sung Kim, MD'1, Sun Yong Kim, MD¹
}

Objective: To correlate quantitative cerebrovascular reserve calculated by acetazolamide - challenged CT perfusion with clinical symptoms in hemodynamically compromised patients with high-grade $(>70 \%)$ carotid stenosis, who did not have evidence of embolic stroke.

Materials and Methods: 37 patients diagnosed as unilateral severe carotid stenosis and 10 age-matched normal controls underwent acetazolamide - challenged CT perfusion. For quantitative measurement, asymmetric index of cerebral blood flow, cerebral blood volume, and mean transit time were determined before and after acetazolamide challenge. Reactivity index was also calculated from asymmetric index of cerebral blood flow before and after acetazolamide challenge.

Results: On visual analysis, all of 14 asymptomatic patients and 4 of 23 symptomatic patients showed bilateral symmetric cerebrovascular reserve on CT perfusion, and 19 symptomatic patients showed decreased cerebrovascular reserve ipsilateral to carotid stenosis. On quantitative analysis, the reactivity index was significantly different between the symptomatic and the asymptomatic groups $(-24 \%$ vs $-8 \%$ in external border zone) but the resting parameters were not. 11 patients with decreased cerebrovascular reserve who underwent carotid stenting showed improved clinical symptoms and quantitative cerebrovascular reserve on follow up CT perfusion.

Conclusion: Compared with resting hemodynamic parameters, quantitative cerebrovascular reserve calculated by CT perfusion is most significantly correlated with clinical symptoms in hemodynamically compromised patients with high-grade carotid stenosis.

Key Words : CT perfusion; Carotid artery stenosis; Stent

Carotid stenosis or occlusion may compromise cerebral hemodynamics (1). Neurological symptoms associated with carotid stenosis are mainly produced by thromboembolic stroke. They can be also attributed to altered cerebral hemodynamics (2). Hemodynamic

'Department of Diagnostic Radiology, Ajou University, School of Medicine, Gyeonggi-do, Korea

Received October 7, 2009;

accepted after revision January 13, 2010.

Correspondence to: Ho Sung Kim, MD, Department of Diagnostic Radiology, Ajou University, School of Medicine, Mt. 5, Woncheondong, Yeongtong-gu, Suwon-si, Gyeonggi-do 442-749, Korea.

Tel. 82-31-219-5857 Fax. 82-31-219-5862

E-mail: J978005@lycos.co.kr

Neurointervention 2010;5:23-31 factors have long been associated with the symptomatic status of stenosis, although their role is controversial (1). A percentage of patients have an insufficient collateral supply and so arterial stenosis can cause a reduction of pressure in the distal arterial vessels. However, the degree of stenosis does not accurately predict hemodynamic status of distal circulation (3).

The impaired cerebral hemodynamics can be identified either by detecting brain tissue at risk or by demonstrating an impaired vasodilatatory response (4). The impaired cerebrovascular reserve (CVR) capacity is reported to be associated with an ischemic stroke, even in asymptomatic patients, as it has been found to be significantly reduced in low-flow infarctions compared with thromboembolic infarctions in patients 
with ipsilateral carotid stenosis (5).

Paired cerebral blood flow (CBF) measurements following a cerebral vasodilatory stimulus to calculate percent changes predict the inferred pre-existing autoregulatory cerebral vasodilation because of reduced cerebral perfusion pressure (4). By using this paired CBF measurements in addition to standard clinical and angiographic studies, it is possible to identify a small subgroup of patients exhibiting a characteristic deficit, namely impairment of the CVR. There is an evidence to indicate that these patients are at particular risk of subsequent stroke, compared to those with similar occlusive lesions but intact CVR (6, 7).

Positron emission tomography (PET), single photon emission CT (SPECT), perfusion-weighted MR imaging, transcranial doppler ultrasonography as well as CT perfusion (CTP) can be used to measure CBF either before or after administration of vasodilator to assess CVR. Although SPECT is an established method for measuring $\mathrm{CBF}$ with or without $\mathrm{ACZ}$ challenge in patients with stroke or carotid disease $(8$, 9), it usually has to be performed in a two-day setting due to tracer kinetics. Moreover, it provides less morphological information than CT or MR imaging. PET can not routinely be applied to patients in many hospitals. The usefulness of dynamic CTP imaging for early diagnosis of acute ischemic stroke has previously been reported, and it has become a promising tool for a quick evaluation of the cerebral circulation in an acute stroke $(10,11)$. Moreover, this imaging modality is much more readily accessible imaging method to assess cerebral hemodynamic status in patients with cerebral steno-occlusive arterial disease than SPECT and PET. However, there are only a few reports on the feasibility of CTP in evaluation of patients with chronic cerebral ischemia (12-14).

We evaluated the value of quantitative CVR calculated by acetazolamide - challenged CTP (ACZ CTP) for identifying hemodynamically compromised group among the patients with high-grade internal carotid artery (ICA) stenosis and correlated it with clinical symptoms.

\section{MATERIALS AND METHODS}

\section{Study Population}

137 patients were referred to our institute through the neurological clinic for CTP of their cerebral perfusion. The inclusion criteria of patients for ACZ - CTP were as follows: normal evidence of infarct on brain MR images (including diffusion-weighted image) except for minimal T2 signal change in internal border zone, digital subtraction angiography (DSA) or CT angiography (CTA) showing unilateral ICA stenosis with $>$ $70 \%$ diameter reduction, contralateral ICA shows normal or stenosis $<20 \%$, and no notable renal insufficiency or allergy to contrast agent. To determine the degree of ICA stenosis, we used the criteria of the North American Symptomatic Carotid Endarterectomy Trial (NASCET) (15). None of the patients had stenoses in intracranial vasculature. Finally, ACZ CTP was prospectively performed in 37 patients. CTP without ACZ challenge was performed in 30 agematched normal controls and ACZ - CTP in 10 agematched normal controls. There were 21 men (age range, 36- 86 years; mean age, 60.3 years) and 16 women (age range, $42-88$ years; mean age, 65.1 years). Among the 37 patients who fulfilled the inclusion criteria, 23 patients were symptomatic and 14 patients were asymptomatic. Symptomatic patients had experienced single or recurrent episodes of transient ischemic attack. Transient neurological deficits were defined as symptoms that lasted for less than 24 hours. All patients who were asymptomatic underwent CTA during medical checkup. In the 5 patients of the symptomatic group, relevant minor infarcts were detected in the internal border zone. Stroke risk factors such as arterial hypertension, generalized arterial occlusive disease and diabetes mellitus were reviewed in all study patients. Our institutional review board approved this study and written informed consent was obtained from every participant in accordance to the guidelines of the institutional review board at our institution.

\section{Imaging Protocol}

The imaging protocol consisted of nonenhanced CT and $\mathrm{CTP}$ before and after $\mathrm{ACZ}$ injection. The mean interval between ACZ - CTP and angiography (DSA or CTA) was 2 days, with a range of $1-5$ days. CTP studies were performed in the transverse plane with use of a 64-channel multi-detector CT scanner (Brilliance 64; Philips Medical Systems, Cleveland, Ohio). CTP consisted of a 60 second series with 30 gantry rotations performed in cine mode during the intravenous administration of iodinated contrast material. Images were acquired and reconstructed at a temporal sampling rate of one image per two seconds, resulting in a series of 30 images for each assessed section. After nonenhanced CT of the whole brain, at the level of basal ganglia that covered all three vascular territories, 
a four $\mathrm{cm}$ thick slab oriented in the transverse plane was defined and the slab was preferred to eight adjacent five-mm-thick sections per location to maximize the signal-to-noise ratio without increasing the dose to the patient. A $50 \mathrm{~mL}$ bolus of non-ionic contrast media (Omnipaque, iodine $300 \mathrm{mg} / \mathrm{mL}$; Amersham Health, Princeton, NJ) was administered into an antecubital vein by using a power injector at an injection rate of $4.5 \mathrm{~mL} / \mathrm{s}$. The acquisition parameters were $80 \mathrm{kVp}$ and $120 \mathrm{mAs}$. CT scanning was initiated 2 seconds after the start of the injection. The gantry angle is parallel to and above the orbital roof to avoid radiation exposure to the lens. The $\mathrm{CT}$ scans were studied once before intravenous infusion of $1000 \mathrm{mg}$ of ACZ (Diamox; Wyeth, Marietta, PA) and again 20 minutes after the infusion of ACZ. All at-rest and ACZ-stress CTP were obtained during the same session, with the patients remaining in supine position.

\section{Data Processing}

CTP data were analyzed by using Brain Perfusion software (Extended Brilliance Workspace v 3.0, Philips Medical Systems, Cleveland, Ohio). This software relies on the central volume principle, which is the most accurate for low injection rates of iodinated contrast material (16). After motion correction and noise reduction are done by using an anisotropic, edgepreserving spatial filter, the software applies curve fitting by a least-mean-squares method to obtain mathematical descriptions of the time-attenuation curves. Then, it applies a closed-form (noniterative) deconvolution to calculate the mean transit time (MTT) map (17). The deconvolution operation requires a reference arterial input function, which selected by the CTP software in a region of interest (ROI) that the user draws around the anterior cerebral artery (ACA) to the stenoses. The relative cerebral blood volume (CBV) map is calculated from the areas under the timeenhancement curves (18). A simple equation combining relative $\mathrm{CBV}$ and MTT values allows the calculation of relative $\mathrm{CBF}$ (relative $\mathrm{CBF}$ ): relative $\mathrm{CBF}=$ relative $\mathrm{CBV} / \mathrm{MTT}$ (17). Finally, the software calculates an automated computerized map of the penumbra and infarct by using relative CBF and relative CBV thresholds, according to a method previously described and validated $(10,11)$.

\section{Data Analysis}

For the visual analysis of parametric maps, two experienced neuroradiologist independently and blindly evaluated the CBV, CBF, and MTT maps before and after ACZ injection for the presence of a perfusion defict and decreased CVR. For the quantitative analysis, an experienced neuroradiologist drew eight standardized polygonal mirrored ROIs manually on the reference CT image over the cortical gray matter of the expected territory of the anterior cerebral artery (ACA), the middle cerebral artery (MCA), and the anterior external border zone (ABZ) and the basal ganglia (BG) bilaterally. Large cortical vessels were excluded automatically. From the each ROI, the absolute values of CBF, CBV, and MTT were calculated.

The cerebral hemodynamic status was also assessed by asymmetric index (AI) and reactivity index (RI). AI was determined by dividing the absolute values in the stenotic hemispheres by those in the nonstenotic sides. $\mathrm{RI}$ was calculated as follows: $\mathrm{RI}(\%)=\left(\mathrm{AI}_{\mathrm{ACZ}}-\right.$ $\left.\mathrm{AI}_{\text {Baseline }}\right) \div \mathrm{AI}_{\text {Baseline }} \times 100$, where $\mathrm{AI}_{\text {Baseline }}$ and $\mathrm{AI}_{\mathrm{ACZ}}$ represented parameters before and after intravenous injection of ACZ, respectively. Perfusion measurements from the baseline hemodynamic values of 30 normal controls and RIs of 10 normal controls underwent ACZ-CTP were used to define the normal ranges. Values outside the normal ranges determined between the mean plus 2 standard deviations (SDs) and that minus 2 SDs were considered to be abnormal.

\section{Statistical analysis}

The relationship of the clinical symptom compared with the visually increased or decreased baseline hemodynamic parameters and CVR was analyzed using chi-square test. Interobserver agreement for the visual analysis of baseline parameters and CVR was measured by using the kappa statistic $(\mathrm{k})$ for nominal data. The AIs of baseline hemodynamic parameters and RIs were compared between the symptomatic and the asymptomatic groups on each ROI location by using the Student t-test or, when appropriate, the MannWhitney U test. The degrees of carotid stenosis were compared between the visibly decreased and normal CVR groups by using the Student t-test. The quantitative improvement of RI before and after CAS was analyzed using paired t-test or, when appropriate, Wilcoxon's signed rank test. A p - value of less than 0.05 was considered to indicate a statistically significant difference.

\section{RESULTS}

All patients underwent ACZ - CTP successfully. No adverse effects were reported after ACZ administration. 
On visual analysis, all patients from both symptomatic and asymptomatic groups displayed longer MTT ipsilateral to high-grade carotid stenosis, which was most pronounced in ABZ. For baseline CBF, there was a trend for slightly lower preoperative values in the symptomatic group than in asymptomatic group but chi-square test showed no statistical significance between the two groups. The CBV values remained
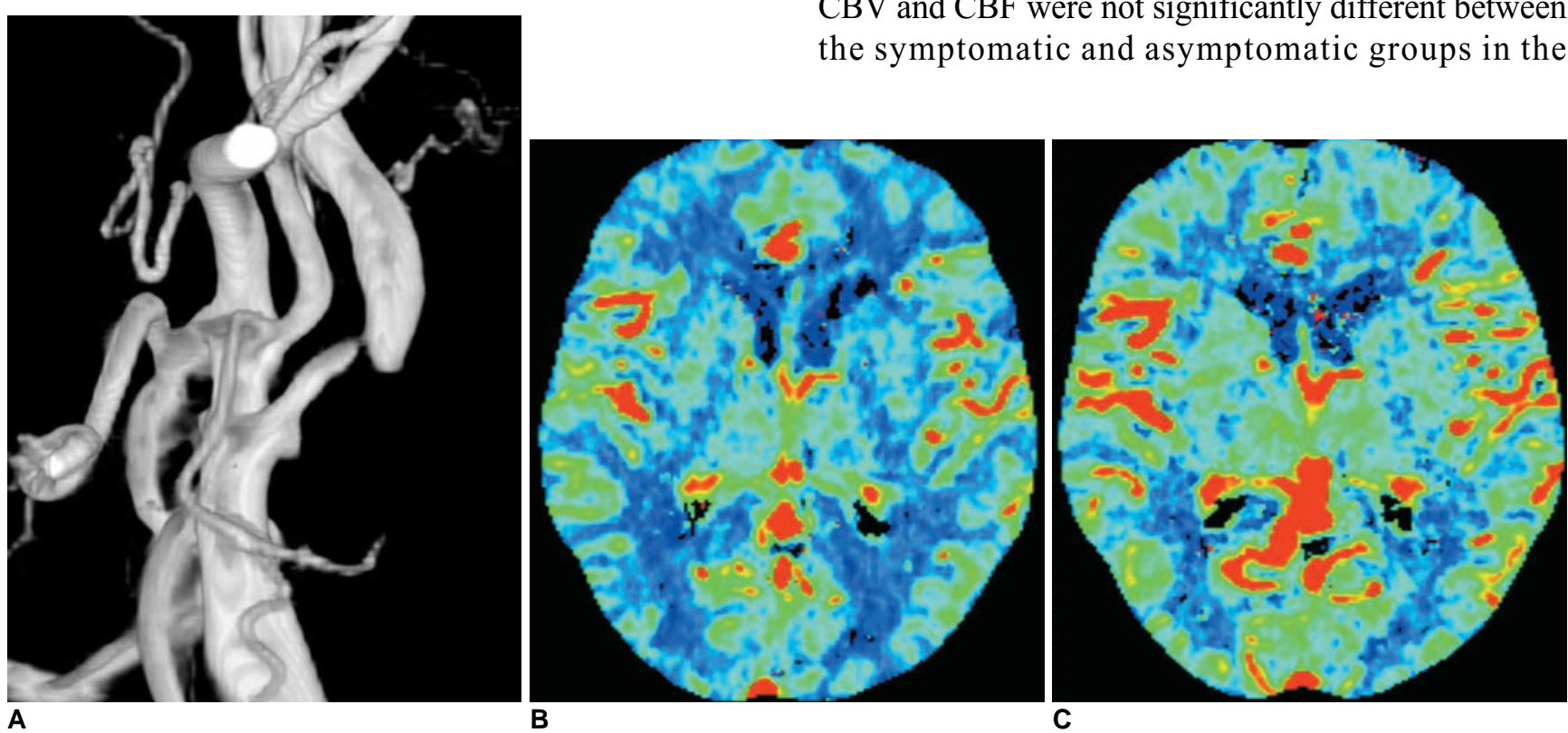

Fig. 1. A 70-year-old male patient with asymptomatic severe left carotid stenosis.

A. 3-D rotational DSA shows focal high-grade left carotid stenosis (> 70\%).

B. Baseline CBF map shows symmetric both hemispheres.

C. Qualitative CVR on CBF map after ACZ injection is not decreased in the stenotic hemisphere.

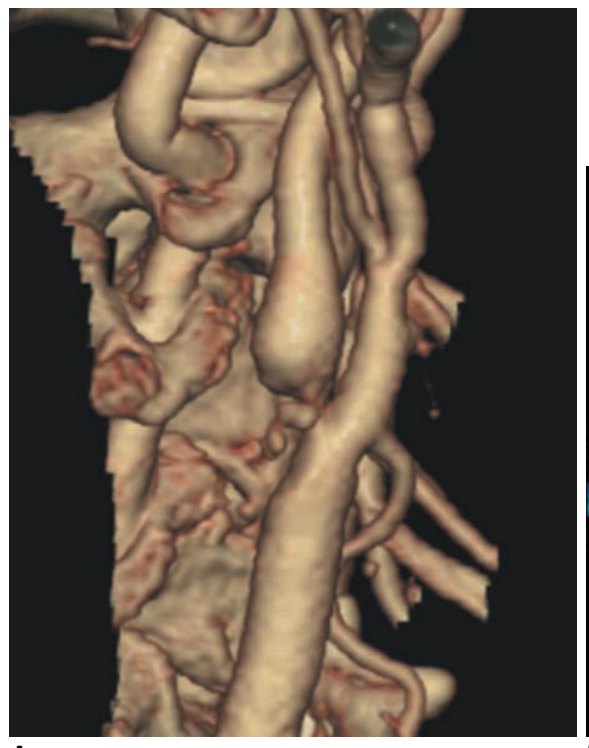

A
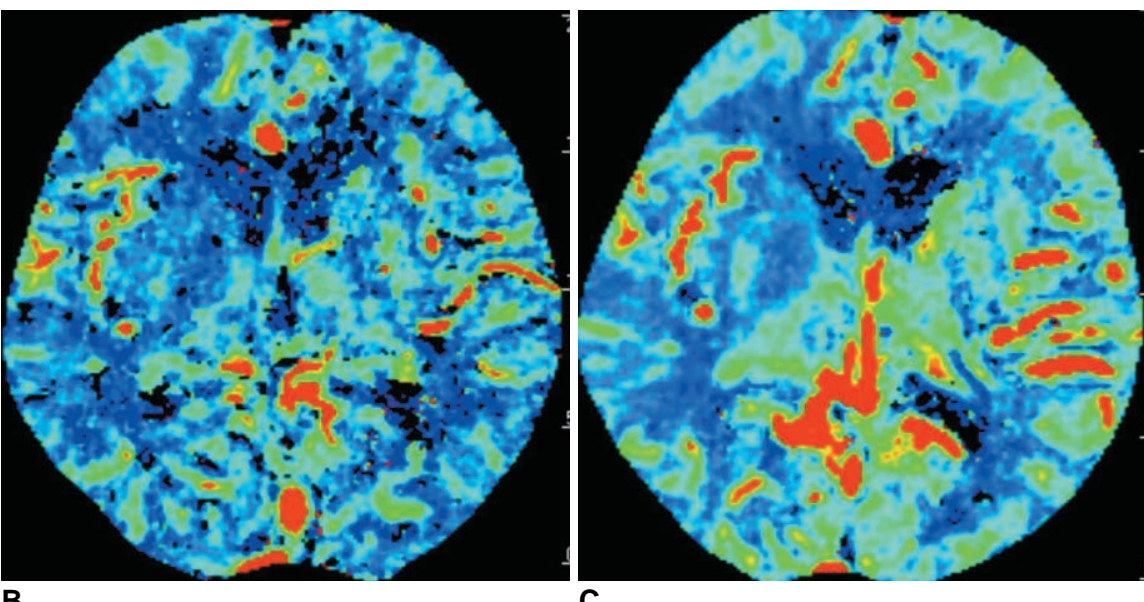

Fig. 2. A 74-year-old male patient with symptomatic severe right carotid stenosis.

A. 3-D CT angiography shows focal high-grade right carotid stenosis (> 70\%).

B. Baseline CBF map shows relatively symmetric both hemispheres.

C. Qualitative CVR after ACZ injection is significantly decreased in the stenotic hemisphere. 
territories of ACA, MCA, ABZ, and BG. The mean AI of baseline MTT in the symptomatic group was significantly $(p<.05)$ higher than that in the asymptomatic group in the MCA territory and ABZ ipsilateral to carotid stenosis (Table 1). The mean RI in the symptomatic group was significantly $(\mathrm{p}<.05)$ lower than that in the asymptomatic group in the MCA territory and ABZ ipsilateral to carotid stenosis (Table 1). The degrees of carotid stenosis were not significantly different between the patients with a visibly decreased CVR and normal CVR. The lowest degree of stenosis with a visually impaired CVR was $79 \%$. 11 patients with decreased qualitative CVR who underwent carotid
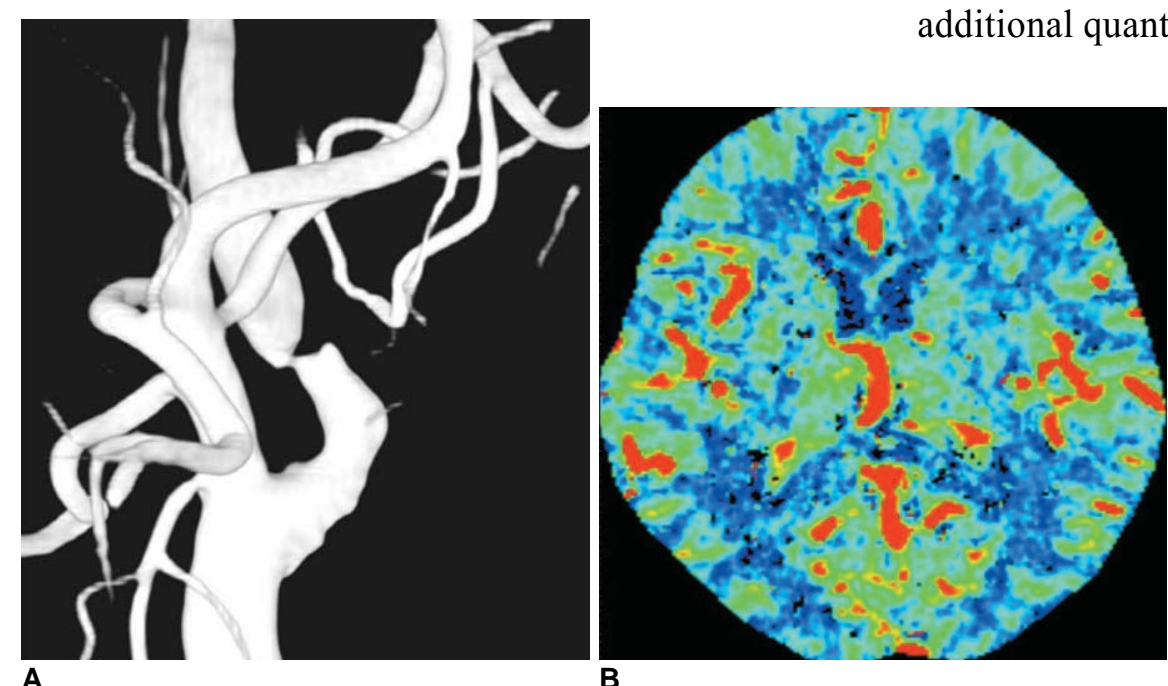

B

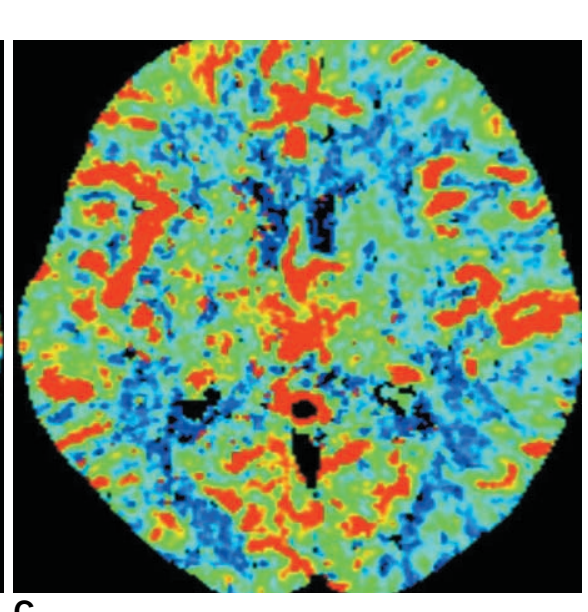

C artery stenting (CAS) showed improved CVR on follow up ACZ - CTP (Fig. 3). In the patients who underwent $\mathrm{CAS}$, the mean RIs in the territories of MCA and ABZ before CAS were significantly increased after CAS and the change in quantitative CVR after CAS correlated with the improvement of the clinical symptoms in all patients who underwent CAS.

\section{DISCUSSION}

The present study of ACZ - CTP in patients with major findings: 1) the CTP is feasible for the evaluation of CVR after ACZ administration and provides additional quantitative hemodynamic information, 2) unilateral high-grade carotid stenosis reveals four

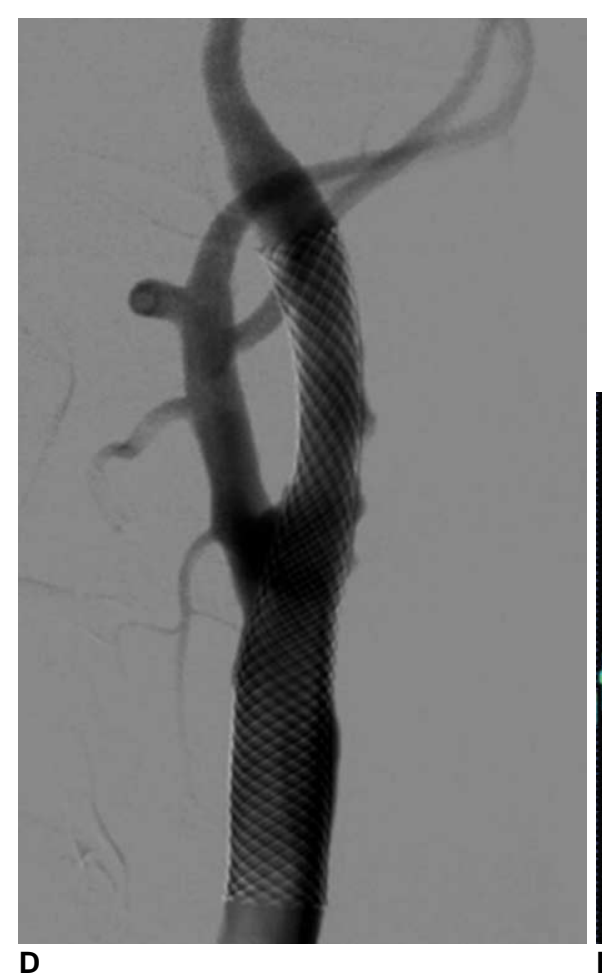

D

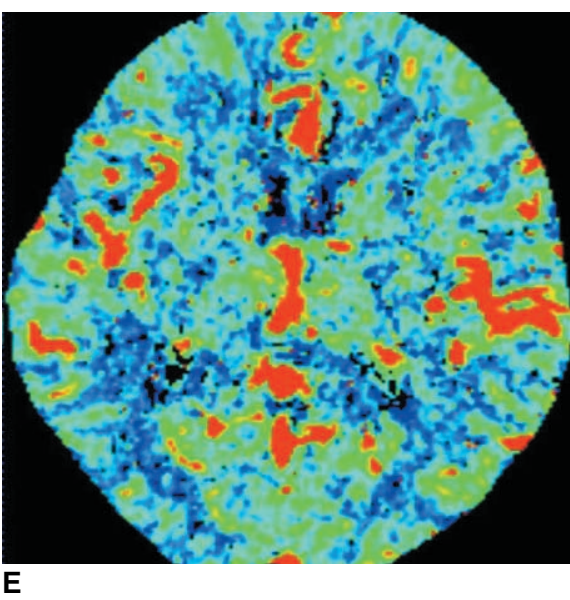

Fig. 3. ACZ - CTP before and after carotid stenting in 55-year-old male patient with high-grade left carotid stenosis.

A. 3-D DSA shows focal high-grade left carotid stenosis (> 70\%).

B. Baseline CBF map shows symmetric CBF between the normal and the stenotic hemispheres.

C. CBF map after ACZ injection shows lack of increase of blood flow in the stenotic hemisphere compared with the normal hemisphere.

D. DSA shows stent placement in the stenotic portion of left ICA.

E. CBF map after ACZ injection shows improved qualitative CVR compared with that before carotid stenting. 
among the hemodynamic parameters before and after ACZ challenge, the RI on the CTP reflecting CVR is most significantly correlated with clinical symptoms but $\mathrm{CBV}$ and CBF underscore the cerebral hemodynamic status and MTT overscore the hemodynamic status as a correlate of the symptomatic state, and 3) in the candidates for CAS, the improvement of CVR after CAS was validated on ACZ - CTP. 4) Normal values of hemodynamic parameters were determined within our institution.

As for the feasibility of the ACZ - CTP for the evaluation of CVR, there was no case presenting any major or minor complications associated with ACZ administration. Moreover, the entire ACZ - CTP study was completed within 30 minutes. While SPECT does not routinely provide quantitative CVR analysis, quantitative analysis using CTP could be made immediately after image processing and this analysis was reproducible. Our second major finding indicates that among the resting and stress hemodynamic parameters, the RI obtained from the AIs of CBF before and after ACZ injection was most significantly correlated with clinical symptoms. Among resting hemodynamic parameters, the most substantial change linked to the hemodynamic effect of the stenosis was found in the MTT parameter. MTT, which is defined as $\mathrm{CBV} / \mathrm{CBF}$, can be measured by using $\mathrm{CT}$ or MR imaging but has thus far been used as a nonspecific indicator of a perfusion disturbance. As shown by previous report (19), before injection of ACZ, MTT was already increased in the hemispheres distal to the stenoses, and the use of the ACZ made MTT maps to reveal clearer asymmetry. Hemodynamic impairment, which is defined by CBF percent change, was postulated to represent true determinant, $40 \%$ of patients with normal CVR had a false-positive result, which is defined by an abnormal baseline MTT value. Although CBF is used mostly in clinical practice, the regional $\mathrm{CBF}$ is an insensitive indicator of the severity of occlusive cerebrovascular disease because it does not change with a small change of cerebral perfusion pressure (20). In our study, MTT and CBF were overlapped between the symptomatic and the asymptomatic groups. Variation in CBV was notably low. CBV should not be sensitive to delay and dispersion of the bolus (21), and in this analysis only very subtle differences between the asymptomatic and symptomatic carotid stenosis groups were seen. As shown by

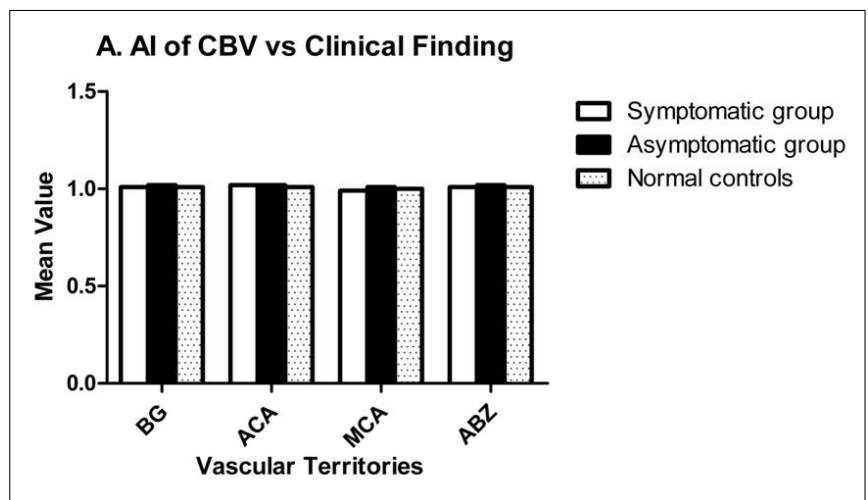

A

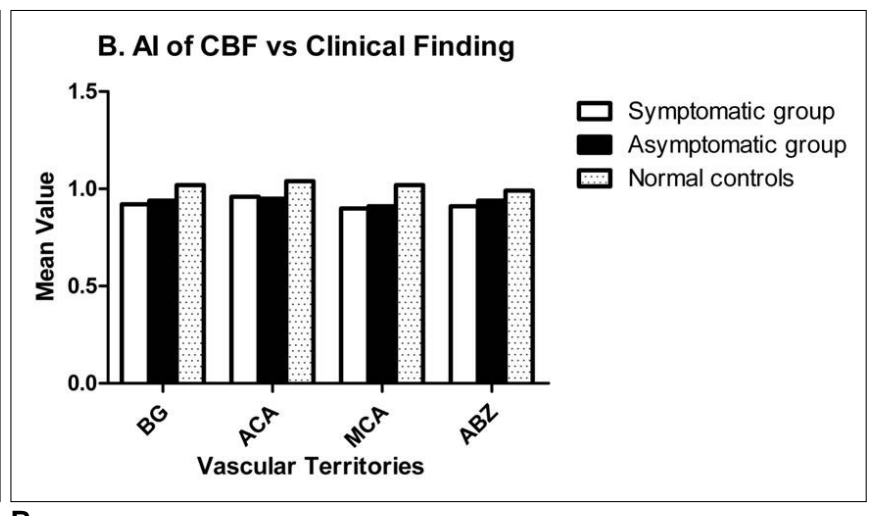

B

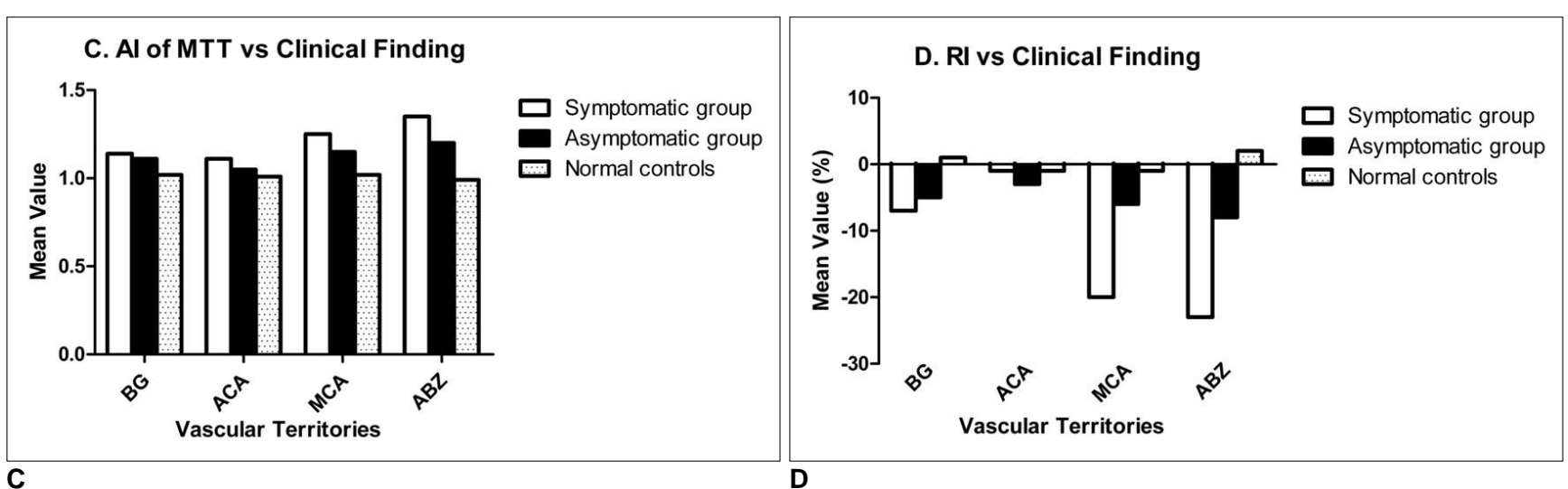

Fig. 4. The differences of mean values of baseline hemodynamic parameters and RI between symptomatic, asymptomatic, and normal control groups. 
Table 1. The Als of Baseline Hemodynamic Parameters and Rls in Each Vascular Territory Between the Symptomatic, Asymptomatic, and Normal Control Groups

\begin{tabular}{llccc}
\hline & & $\begin{array}{c}\text { Symptomatic } \\
\text { group }\end{array}$ & $\begin{array}{c}\text { Asymptomatic } \\
\text { group }\end{array}$ & Controls \\
\hline Al of CBV & BG & 1.01 & 1.03 & 1.01 \\
& ACA & 1.03 & 1.02 & 1.01 \\
& MCA & 0.99 & 1.01 & 1.00 \\
Al of CBF & ABZ & 1.02 & 1.01 & 1.01 \\
& BG & 0.92 & 0.95 & 1.02 \\
& MCA & 0.97 & 0.96 & 1.04 \\
Al of MTT & 0.90 & 0.92 & 1.02 \\
& ABZ & 0.92 & 0.93 & 0.99 \\
& ACA & 1.15 & 1.11 & 1.02 \\
& MCA & 1.11 & 1.06 & 1.01 \\
& ABZ & 1.26 & 1.15 & 1.02 \\
RI (\%) & BG & $-8 \%$ & $-5 \%$ & 0.99 \\
& ACA & $-2 \%$ & $-4 \%$ & $-1 \%$ \\
& MCA & $-21 \%$ & $-5 \%$ & $-1 \%$ \\
& ABZ & $-24 \%$ & $-8 \%$ & $2 \%$ \\
\hline
\end{tabular}

Note- $\mathrm{Al}=$ asymmetric index, $\mathrm{CBV}=$ cerebral blood volume, $\mathrm{CBF}$ = cerebral blood flow, $\mathrm{MTT}=$ mean transit time, $\mathrm{RI}=$ reactivity index, $B G=$ basal ganglia, $A C A=$ anterior cerebral artery territory, $\mathrm{MCA}=$ middle cerebral artery territory, $\mathrm{ABZ}=$ anterior border zone.

previous studies $(19,22)$, measurements of CBV showed that there was no difference in hemispheric ratio before and after $\mathrm{ACZ}$ challenge or in percent change between stenotic and nonstenotic hemispheres. CBV is unlikely to be the most sensitive indicator of hemodynamic reserve $(22,23)$. CVR was severe enough to be visually detected in more than half of the symptomatic carotid stenosis group and was significantly associated with symptomatic status. The prevalence of perfusion deficit in the symptomatic carotid stenosis group is a reminder of the potentially confounding role of chronic hypoperfusion in the setting of acute ischemia because it may be attributed erroneously to acute thrombosis and be regarded as tissue at risk $(24,25)$. In such cases, DSA demonstrating a tight carotid stenosis without intracranial arterial occlusions should arouse suspicion for a chronic state of hypoperfusion.

Compared with other perfusion techniques such as PET and SPECT, CTP has the advantages of improved spatial resolution and easy accessibility. CTP studies, even combined with ACZ challenge, are also rapid and require little time to postprocess. Additional hemodynamic parameters such as CBV and MTT can also be obtained by CTP. Moreover, CTP can provide both morphological and hemodynamic information in a single investigation. The quantitative results potentially available with CTP may offer an advantage over qualitative techniques such as SPECT and perfusionweighted MR imaging.

As previously reported, the statistically significant correlation of CBF measurements between CTP and PET demonstrates clearly that CVR in symptomatic chronic carotid stenotic disease can accurately be measured by means of CTP (1). However, not statistically significant tendency to underestimate the baseline CBF values in CTP led to different estimations of the CVR capacity between CTP and PET. Moreover, previous reports $(26,27)$ showed the overestimation of CBF in CTP compared with PET after ACZ challenge. This tendency can be attributed to the presence of large cerebral vessels on the surface of the brain as well as to the presence of perforating arteries in the basal ganglia. In the present study, we did not assess CVR by using absolute percent changes of the hemodynamic parameters including $\mathrm{CBF}$ which were variable and not reproducible in our study. Therefore, we calculated the AIs and RIs of the hemodynamic parameters which were reproducible within and between observers. The overestimation of the CBF values by CTP was found statistically significant by Kudo et al. (27), who tried to minimize this effect with a vascular pixel elimination method. We also applied the automatic vascular pixel elimination method.

There are several limitations regarding the quantification of CTP as used clinically. On the basis of the deconvolution method, an input artery should ideally be chosen from the most proximal large feeding vessels which directly supply the tissue of interest. However, it is not always possible to select such an input artery in clinical practice. These limitations may result in the wide range of absolute measurements, making it difficult to detect abnormal values. Intrasubject normalization of the data is frequently used to deal with these problems: The use of hemispheric ratios takes advantage of the basic symmetry of the brain to improve sensitivity for identifying localized disease. There are no standardized guidelines for placing ROIs. Larger ROIs may result in greater volume averaging of gray and white matters, thus lowering quantitative values for $\mathrm{CBF}$, compared with the results obtained when using smaller ROIs centered in the cortex. The observer of our study manually drew ROIs over the cortical gray matter of the expected territory of ACA, $\mathrm{MCA}, \mathrm{ABZ}$, and BG, with care not to involve substan- 
tial parts of the cerebral white matter and large cortical blood vessels were automatically excluded from the ROIs.

The ACZ - CTP can provide accurate quantitative information about the CVR. Compared with baseline hemodynamic parameters, quantitative CVR (=RI) calculated by ACZ - CTP was the most significantly correlated with clinical symptoms in homogeneous patient groups with unilateral high-grade carotid stenosis. The preoperative hemodynamic adaptation is inferior in symptomatic carotid stenosis patients in comparison to asymptomatic patients; this may be detected particularly as an decreased CVR in ACZCTP. The asymptomatic carotid stenosis group represented a more stable hemodynamic constitution.

\section{Acknowledgments}

The authors acknowledge Scott Pohlman in the Philips Medical Systems for his coorperation and valuable technical advices.

\section{References}

1. Klijn CJM, Kappelle LJ, Tulleken CAF, van Gijn J. Symptomatic carotid artery occlusion: a reappraisal of hemodynamic factors. Stroke 1997;28:2084-2093

2. Bisdas S, Nemitz O, Berding G, Weissenborn K, Ahl B, Becker $\mathrm{H}$, et al. Correlative assessment of cerebral blood flow obtained with perfusion CT and positron emission tomography in symptomatic stenotic carotid disease. Eur Radiol 2006;16:2220-2228

3. Powers WJ, Press GA, Grubb RL Jr, Gado M, Raichle ME. The effect of hemodynamically significant carotid artery disease on the hemodynamic status of the cerebral circulation. Ann Intern Med 1987; 106:27-34

4. Derdeyn CP, Grubb RL Jr, Powers WJ. Cerebral hemodynamic impairment: methods of measurement and association with stroke risk. Neurology 1999;53:251-259

5. Ringelstein EB, Weiller C, Weckesser M, Weckesser S. Cerebral vasomotor reactivity is significantly reduced in low-flow as compared to thromboembolic infarctions: the key role of the circle of Willis. J Neurol Sci 1994;121:103-109

6. Kleiser B, Widder B. Course of carotid artery occlusions with impaired cerebrovascular reactivity. Stroke 1992;23:171-174

7. Yonas H, Smith HA, Durham SR, Pentheny SL, Johnson DW. Increased stroke risk predicted by compromised cerebral blood flow reactivity. J Neurosurg 1993;79:483-489

8. Kuroda S, Houkin K, Kamiyama H, Mitsumori K, Iwasaki Y, Abe $\mathrm{H}$. Long-term prognosis of medically treated patients with internal carotid or middle cerebral artery occlusion: can acetazolamide test predict it? Stroke 2001;32:2110-2116

9. Raynaud C, Rancurel G, Tzourio N, Soucy JP, Baron JC, Pappata $\mathrm{S}$, et al. SPECT analysis of recent cerebral infarction. Stroke 1989;20:192-204

10. Wintermark M, Reichhart M, Cuisenaire O, Maeder P, Thiran JP, Schnyder $\mathrm{P}$, et al. Comparison of admission perfusion computed tomography and qualitative diffusion- and perfusion-weighted magnetic resonance imaging in acute stroke patients. Stroke 2002;33:2025-2031

11. Wintermark M, Reichhart M, Thiran JP, Maeder P, Chalaron M, Schnyder P, et al. Prognostic accuracy of cerebral blood flow measurement by perfusion computed tomography, at the time of emergency room admission, in acute stroke patients. Ann Neurol 2002;51:417-432

12. Eastwood JD, Alexander MJ, Petrella JR, Provenzale JM. Dynamic CT perfusion imaging with acetazolamide challenge for the preprocedural evaluation of a patient with symptomatic middle cerebral artery occlusive disease. AJNR Am J Neuroradiol 2002;23:285-287

13. Furukawa M, Kashiwagi S, Matsunaga N, Suzuki M, Kishimoto K, Shirao S. Evaluation of cerebral perfusion parameters measured by perfusion CT in chronic cerebral ischemia: comparison with xenon CT. J Comput Assist Tomogr 2002;26:272-278

14. Nabavi DG, Cenic A, Craen RA, Gelb AW, Bennett JD, Kozak R, et al. CT assessment of cerebral perfusion: experimental validation and initial clinical experience. Radiology 1999;213:141-149

15. North American Symptomatic Carotid Endarterectomy Trial. Methods, patient characteristics, and progress. Stroke 1991;22:711-720

16. Wintermark M, Maeder P, Thiran JP, Schnyder P, Meuli R. Quantitative assessment of regional cerebral blood flows by perfusion CT studies at low injection rates: a critical review of the underlying theoretical models. Eur Radiol 2001;11:1220-1230

17. Axel L. Tissue mean transit time from dynamic computed tomography by a simple deconvolution technique. Invest Radiol 1983;18:94-99

18. Ladurner G, Zilkha E, Iliff D, du Boulay GH, Marshall J. Measurement of regional cerebral blood volume by computerized axial tomography. J Neurol Neurosurg Psychiatry 1976;39:152155

19. Chen A, Shyr MH, Chen TY, Lai HY, Lin CC, Yen PS. Dynamic CT Perfusion Imaging with Acetazolamide Challenge for Evaluation of Patients with Unilateral Cerebrovascular StenoOcclusive Disease. AJNR Am J Neuroradiol 2006;27:1876-81

20. Powers WJ. Cerebral hemodynamics in ischemic cerebrovascular disease. Ann Neurol 1991;29:231-240

21. Calamante F, Gadian DG, Connelly A. Delay and dispersion effects in dynamic susceptibility contrast MRI: simulations using singular value decomposition. Magn Reson Med 2000;44:466-473

22. Derdeyn CP, Videen TO, Yundt KD, Fritsch SM, Carpenter DA, Grubb RL, et al. Variability of cerebral blood volume and oxygen extraction: stages of cerebral haemodynamic impairment revisited. Brain 2002;125:595-607

23. Lythgoe DJ, Ostergaard L, William SC, Cluckie A, BuxtonThomas M, Simmons A, et al. Quantitative perfusion imaging in carotid artery stenosis using dynamic susceptibility contrastenhanced magnetic resonance imaging. Magn Reson Imaging 2000;18:1-11

24. Neumann-Haefelin T, Wittsack H-J, Fink GR, Wenserski F, Li TQ, Seitz RJ, et al. Diffusion- and perfusion-weighted MRI: influence of severe carotid artery stenosis on the DWI/PWI mismatch in acute stroke. Stroke 2000;31:1311-1317

25. Schlaug G, Benfield A, Baird A, Siewert B, Lövblad KO, Parker RA, et al. The ischemic penumbra: operationally defined by diffusion and perfusion MRI. Neurology 1999;53:1528-1537

26. Gillard JH, Minhas PS, Hayball MP, Bearcroft PW, Antoun NM, 
Freer CE, et al. Assessment of quantitative computed tomographic cerebral perfusion imaging with $\mathrm{H}_{2}{ }^{15} \mathrm{O}$ positron emission tomography. Neurol Res 2000;22:457-464

27. Kudo K, Terae S, Katoh C, Oka M, Shiga T, Tamaki N, et al.
Quantitative cerebral flow measurement with dynamic perfusion CT using the vascular-pixel elimination method: comparison with $\mathrm{H}_{2}{ }^{15} \mathrm{O}$ positron emission tomography. AJNR Am J Neuroradiol 2003;24:419-426

신경중재치료의학 2010;5:23-31

\title{
심한 경동맥협착 환자에서 아세타졸아마이드 부하 CT 관류영상의 유용성
}

\author{
${ }^{1}$ 아주대학교병원 영상의학과
}

\section{김호성' · 김선용'}

목적: $70 \%$ 이상의 심한 경동맥 협착 환자의 임상증상의 유무와 아세타졸아마이드 부하 관류 CT 영상을 이용한 정량적 뇌혈류 예비량을 비교하고자 한다.

대상 및 방법: 아세타졸아마이드 부하 관류 CT 영상을 시행 받은 37명의 편측성 심한 경동맥 협착 환자와 10 명의 정상대조군을 대상으로 하였다. 정량적 분석을 위해 뇌혈류량, 뇌혈류용적, 및 평균통과시간의 비대칭지표 (asymmetric index)를 아세타졸아마이드 부하 전후에 측정하였다. 반응지표(reactivity index)는 아세타졸 아마이드 부하 전후의 뇌혈류량 비대칭지표를 이용하여 계산하였다.

결과: 정성적 분석에서 23 명의 유증상 경동맥협착 환자중 19 명에서 경동맥협착과 같은편의 대뇌 반구에 뇌혈류 예비량의 감소 소견을 보였다. 정량적 분석에서 유증상과 무증상의 경동맥 협착 환자집단 사이에 반응지표 의 유의한 차이를 보였다. (-24\% vs $-8 \%)$ 뇌혈류 예비량이 감소된 11명의 환자에서 스텐트삽입을 시행한 결과 모든환자에서 임상증상의 호전과 반응지표의 호전을 보였다.

결론: 심한 경동맥 협착 환자에서 정량적 뇌혈류 예비량 (반응지표)은 환자의 임상 증상과 연관이 있다.

Key Words : CT perfusion; Carotid artery stenosis; Stent 